\title{
AZ ISKOLAI SIKER AZ ADHD TÜNETEK TÜKRÉBEN
}

\section{SCHOOL SUCCESS OF STUDENTS WITH AND WITHOUT ADHD SYMPTOMS}

\author{
Bányai Brigitte-Ildikó, Jancsó-Farcas Susana
}

\begin{abstract}
Are students with ADHD symptoms more successful in school compared to their asymptomatic peers? This paper aimed to explore some key variables of school success among Hungarian students aged 14-19 years. Mindset, school performance, performance motivation, subjective and school well-being of adolescents with and without ADHD symptoms were compared. A total of 106 students participated in the study, 56.6\% were female. According to the results, based on self-reported questionnaires $43 \%$ had attention difficulties, and $45 \%$ had hyperactivity symptoms, however only $2,8 \%$ of students were diagnosed with ADHD. The results of the current study show decreased school success of students with attention difficulties and hyperactivity symptoms. Lower school performance (in main subjects as: Hungarian language, Romanian language, mathematics, previous term average), performance motivation and school well-being were revealed among students with ADHD symptoms (both attention difficulties and hyperactivity symptoms). In addition, lower levels of subjective well-being were revealed among students struggling with hyperactivity symptoms. Differences between mindsets were also explored. Nearly twice as many students with hyperactivity symptoms $60,4 \%$ had a fixed mindset, while among asymptomatic students only $36,2 \%$.
\end{abstract}

Keywords: ADHD, attention difficulties, hyperactivity symptoms, mindset, school performance, performance motivation, subjective well-being, school well-being

\section{A kutatás elméleti megalapozása}

A mentális egészségi rendellenességek között az ADHD, azaz a figyelemhiányos hiperaktivitás zavar, az egyik leginkább aluldiagnosztizált és félreértett állapot. Az Amerikai Pszichiátriai Társaság (APA, 2013) korszerüsített, új diagnosztikus rendszere, a DSM-5 meghatározása szerint az ADHD egy a fejlődési periódus kezdetekor megjelenő neurológiai fejlődési zavar, mely káros szintü figyelmetlenséggel, hiperaktivitással és impulzivitással jár. Annak ellenére, hogy az ADHD tünetei gyermekkorban megjelennek, a tünetek többsége pedig serdülőkorban és felnőttkorban is fennáll. Noha a hiperaktivitás tünetei tinédzserkorban általában csökkennek, a figyelmetlenség és a gyenge impulzivitáskontroll a tizenévesek és a felnőttek körében is jelentősen kihat a mindennapokra (National Institutes of Mental Health, 2016).

Az ADHD kiváltó okait a mai napig nem sikerült teljes egészében feltérképezni. Egyes megközelítések szerint genetikai alapú rendellenességről van szó, az örökletesség szerepe 80\%-ra tehető az ikertanulmányok alapján (Csiky, 2021.). Neurobiológiai szempontból megközelítve az ADHD megértéséhez a végrehajtó funkciók hátterében meghúzódó neuroanatómiai struktúrák és funkciók feltérképezése szükséges, hiszen számos vizsgálat bizonyítja, hogy az ADHD esetén egyértelmü eltérések mutathatók ki a végrehajtó funkciók (tervezés, kivitelezés, irányított figyelem, munkamemória és gátlás), a viselkedés szabályozásához, az önkontrollhoz és döntéshozatalhoz, valamint a motoros aktivitás, a figyelem és az érzelem szabályozásához köthető területeken (Imre, 2004). A genetikai és neurobiológiai hatások mellett a környezeti tényezők is hozzájárulhatnak az 
ADHD kialakulásához. A legjelentősebb környezeti hatások közé tartozik a terhesség alatti anyai dohányzás, a méhen belüli magzati alkohol, az ólommérgezés, illetve gyógyszer ártalom (Csiky, 2021.).

Kutatásokban a diákok, egyetemi hallgatók szemléletmódja és iskolai teljesítménye közötti kapcsolatot is vizsgálták. Dweck (2000) szerint azon diákok, akik konkrét tanulási céllal rendelkeznek határozottabban teljesítenek, mivel nem az a céljuk, hogy okosak legyenek, hanem hogy tanulás révén fejlődjenek. Ezen diákokra általában a fejlődésorientált gondolkodásmód jellemző, mely azt sugallja, hogy képességeik erőfeszítésekkel és a megfelelő stratégiákkal javítható. A tanulásban való kitartás arra ösztönzi a diákokat, hogy új dolgokat próbáljanak ki különböző stratégiákat alkalmazva.

Az ADHD-val élö személyek gyakran küzdenek alacsony önértékeléssel, negatív énképpel, emiatt pedig jelentős hátránnyal a tanulás terén (Csiky, 2021.). Az ADHD-val küzdő diákok gyakran rögzült gondolkodásmóddal rendelkeznek, az ismétlődő negatív visszajelzések és a gyakori kudarcok hatására (Whiteman és Novotni, 1995), emiatt csökken önbizalmuk, motivációjuk, bizonytalanná válnak (Yee, 2018) és egy olyan életutat követnek, amelyben nem rendelkeznek konkrét célokkal (Dweck, 2000).

A motiváció szorosan kapcsolódik az egyének gondolkodásmódjához. A teljesítménnyel kapcsolatos elvárások jelentős hatást gyakorolnak ugyanis arra, hogy ki mennyire lesz motivált a feladatvégzés közben, így akár az iskolai teljesítmény, a tanulási tevékenység tekintetében is meghatározó (Fejes, Kun és Medvés, 2015). Azok a hallgatók, akik negatív önértékeléssel rendelkeznek és már a feladat elkezdése előtt is úgy érzik, nem lesznek sikeresek a feladat teljesítésében, egy rögzült gondolkodásmódót vesznek fel, mely a feladatvégzéshez szükséges kitartás hiányához vezet. Ugyanakkor ezen hallgatók inkább az egyszerủ feladatokat választják, hogy elrejtsék az általuk vélt gyenge képességeiket és megakadályozzák a negatív eredményeket (Dweck, 2006). A sikerorientált személyek kitartóak, biztosak képességeikben. A kudarc esetén sem veszítik el a kedvüket, mivel többnyire belső, de nem állandó tényezőket tesznek felelössé a kudarcért. A kudarckerülő személyek ezzel szemben kudarc esetén hamar feladják a küzdelmet és a sikerekről sem hiszik el, hogy saját maguknak köszönhetik. Sikerüket hajlamosak külső, tölük független tényezöknek tulajdonítani, mint például a szerencse, kudarcaikért pedig képességeik hiányát teszik felelössé, melyek belső és állandó tényezők. Ez az oka annak, hogy a sikernek nem tudnak igazán örülni, a kudarcok pedig túlságosan elkeserítik őket. Mindezek hátterében a szorongás és a saját képességeikkel szembeni bizonytalanság állhat (Fodor, 2007), vagy egy rögzült szemléletmód (Dweck, 2006).

Számos elmélet szerint az ADHD-s serdülők egyik alapvető problémája a motiváció hiánya (Volkow, Wang és Swanson, 2011). Ezen elméletek szerint az ADHD-val élő diákokra kevésbé hat ösztönzően a megerősítés, mint a tipkusan fejlődő társaikra és ezért nem is motiváltak arra, hogy társaikhoz hasonló erőfeszítésekkel dolgozzanak (Dovis, 2014).

Az iskolai eredményesség és motiválhatóság mellett a serdülőkorúak szubjektív jóllétének vizsgálata is gyakran megjelenik a pszichológiai és a neveléstudományi kutatásokban, hiszen eme változók kiemelkedő fontosággal bírnak az iskolai eredményesség szempontjából. Hamvai és Pikó (2009) vizsgálata szerint a serdülők szubjektív jóllétének egyik meghatározó tényezője a jó iskolai eredmények. Az iskolai klíma, az iskolával kapcsolatos pozitív érzések, illetve az iskolai teljesítmény egyaránt meghatározza az élettel való megelégedettséget és a szubjektív jóllét összetevőit. Kutatások szerint a jóllét szintje nem jelzi előre közvetlenül az iskolai teljesítményt, viszont a magasabb jólléti mutatókkal rendelkező diákok jobban teljesítenek az iskolában és ritkábban vesznek részt kockázatos viselkedésben (Vieno, Santinello, Galbiati és Mirandola, 2004; Aldridge, Fraser, Fozdar, Ala'i, Earnest és Afari, 2016). Az iskoláskorú gyerekek szubjektív jóllétének vizsgálata feltételezi, hogy a szubjektív jóllétet az iskolai jóllétként való értelmezésként fogjuk fel (Nagy, Jámbori, Gál és Kasik, 2019). 


\section{A kutatás hipotézisei}

Kutatásunk arra a kérdésre keresi a választ, hogy van-e szignifikáns különbség az ADHD-s tünetekkel jellemezhető és nem jellemezhető serdülők iskolai sikerében. Hipotéziseink:

H1: Az ADHD tüneteivel jellemezhető diákok nagyobb arányban élnek át nehézségeket az olyan területeken, mint a koncentráció, érzelem- és viselkedésszabályzás, valamint a másokkal való érintkezés.

H2: Azon diákok, akiknél az ADHD tünetei megjelennek gyengébb iskolai eredményeket érnek el, alacsonyabb a teljesítménymotivációjuk, és nagyobb arányban jellemző rájuk a rögzült szemléletmód, azon társaikhoz képest, akik nem jellemezhetőek ezekkel a tünetekkel.

H3: Az ADHD-s tünetekkel jellemezhető diákok alacsonyabb jólléti mutatókkal rendelkeznek, mint azon társaik, akik esetén nem jelentkeznek ezek a tünetek.

\section{A kutatás résztvevői}

Kutatásunkban $\mathrm{N}=106$ serdülőkorú diák vett részt, életkorukat tekintve 14-19 év közöttiek $(\mathrm{M}=16.30$, $\mathrm{SD}=1.26$ ). A résztvevők 56,6\%-a nő nemü, s 2,8\%-uk rendelkezik ADHD diagnózissal, 21,7\%-uk nem tud arról, hogy rendelkezne ilyen diagnózissal, míg a maradék 75,5\% biztos benne, hogy nincs ADHD diagnózisa. A diagnózissal rendelkező személyek közül kettőnél főként figyelemzavar (figyelemhiány), míg egy esetén kombinált típusú ADHD (figyelemhiány és hiperaktivitás) volt azonosítva.

\section{Felhasznált eszközök}

A résztvevők egy online formátumú kérdőívcsomagot töltöttek ki, amely a demográfiai adatokon belül arra is rákérdezett, hogy volt-e ADHD-val vagy egyéb pszichiátriai/orvosi zavarral diagnosztizálva.

\section{ADHD Önbeszámoló Skála (ADD/H Adolescent Self-Report Scale, Robin \& Vandermay, 1996)}

Az ADD/H Adolescent Self-Report Scale egy önbeszámolós kérdőív a serdülőkorú diákok számára, mely a résztvevők ADHD tüneteit méri fel. A kérdőív 11 tételt tartalmaz, melyen egy 0-tól 3-ig terjedő skálán $(0=$ egyáltalán nem jellemző, $3=$ nagyon jellemző $)$ dönti el a kitöltő, hogy a felsorolt tünetek mennyire jellemzőek rá. A skála Cronbach alpha értéke $\alpha=0,87$.

Képességek és Nehézségek Kérdöiv (Strengths \& Difficulties Questionnaire-SDQ, Goodman, 1997)

Az SDQ kérdőív 25 tétele 5 , egyenként 5 tételből álló skálába csoportosítható. Kutatásunkban két alskálát alkalmaztunk: a Viselkedési problémák alskála, valamint a Hiperaktivitás alskála 5-5 tételét. A résztvevők egy 0 -tól 2 -ig terjedő skálán $(0=$ nem igaz, $2=$ határozottan igaz) jelölik meg, hogy mennyire jellemző rájuk az adott állítás. A viselkedési problémák alskála Cronbach alpha értéke $\alpha=0,609$; a hiperaktivitás alskála $\alpha=0,76$.

\section{Fejlödö Személeletmód Skála (Growth Mindset Scale -GMS, Dweck, 1999, 2006)}

A 3 itemes Growth Mindset Scale segítségével igyekeztünk felmérni, hogy a kutatásban résztvevő diákok milyen típusú szemléletmóddal rendelkeznek. Az 1-től 6-ig terjedő skálára (1=teljes mértékben egyetértek, $6=$ =egyáltalán nem értek egyet) adott válaszok megmutatják, hogy a válaszadók mennyire értenek egyet abban, hogy az intelligenciájuk erőfeszítéseik által megváltoztatható. A skála Cronbach alpha értéke $\alpha=0,88$.

Személyiségre vonatkozó Szemléletmód Skála ('Kind of Person' Implicit Theory Scale, Dweck, 1999) 
A 8 itemes Kind of Person Implicit Theory Scale-t alkalmaztuk annak felmérésére, hogy megnézzük, a kutatásban résztvevő diákok mennyire hisznek a személyiség és jellembeli változásokban. A válaszadók egy szintén 1-töl 6-ig terjedő skálát (1=teljes mértékben egyetértek, 6=egyáltalán nem értek egyet) használnak annak bizonyítására, hogy mennyire értenek egyet az olyan állításokkal, amelyek a személyiség jellembeli megváltoztatására irányulnak. A skála magasabb pontszáma azt jelzi, hogy a résztvevő inkább fejlődésfókuszú szemléletmóddal rendelkezik, míg az alacsonyabb pontszámok azt mutatják, hogy a válaszadónak rögzített szemléletmódja van. A skála Cronbach alpha értéke $\alpha=0,78$.

\section{$3 \times 2$ Teljesités-Cél Kérdőiv (Elliot, Murayama és Pekrun, 2011)}

A serdülőkorú diákok teljesítménymotivációjának mérésére a 3×2 Teljesítés-Cél Kérdőívet alkalmaztuk. A teljesítménymotivációt mérö kérdőív 18 tételt tartalmaz, ahol az egyéneknek egy 1-től 5-ig terjedő skálán (1-nem igaz rám, 5-határozottan igaz rám) jellemezhetik, hogy mennyire igaz rájuk nézve a megadott kijelentés. A magas pontszám azt jelzi, hogy az adott személy motivált arra, hogy a feladatot minél jobban teljesítse, míg az alacsony pontszám alacsony teljesítménymotivációra utal. A skála Cronbach alpha értéke $\alpha=0,95$.

\section{5 tételes WHO Jól-lét Kérdőív (Well-Being Index-5, WBI-5, WHO, 1998)}

A résztvevők szubjektív jóllétének vizsgálatára az 5 tételes WHO Jól-lét Kérdőívet használtuk. A kérdőív 5 tételt tartalmaz, ahol az egyének egy 0 -tól 3-ig terjedő skálán $(0=$ egyáltalán nem jellemző, $3=$ teljesen jellemzö) jelezhetik, hogy hogyan érezték magukat az elmúlt két hét során. A magas pontszám magas jólléti mutatókra utal, míg az alacsony pontszám alacsony szubjektív jóllétet jelent. A skála Cronbach alpha értéke $\alpha=0,78$.

\section{Iskolai Jóllét Kérdőiv (Hascher, 2004)}

Az Iskolai Jóllét Kérdőív egy rövidített változatát használtuk, mely 6 állítást tartalmaz, s a tanulók egy 1-től 3-ig terjedő skálán (1=egyáltalán nem jellemző, 3=teljesen jellemzö) jelölik meg, hogy hogyan érezték magukat az iskolában az elmúlt két hét során. A magas pontszám magas iskolai jóllétre utal, míg az alacsony pontszám arra utal, hogy az adott személy kevésbé érezte jól magát az iskolában az elmúlt két hétben. A skála Cronbach alpha értéke $\alpha=0,72$.

\section{A kutatás eredményeinek bemutatása}

Első hipotézisként feltételeztük, hogy az ADHD tüneteivel jellemezhető diákok nagyobb arányban élnek át nehézségeket az olyan területeken, mint a koncentráció, érzelem- és viselkedésszabályzás, valamint a másokkal való érintkezés. Ezt az SDQ kérdőív segítségével mértük fel és a Chi négyzet próbát végeztünk ennek a vizsgálatára (lásd 1.Ábra és 2.Ábra).

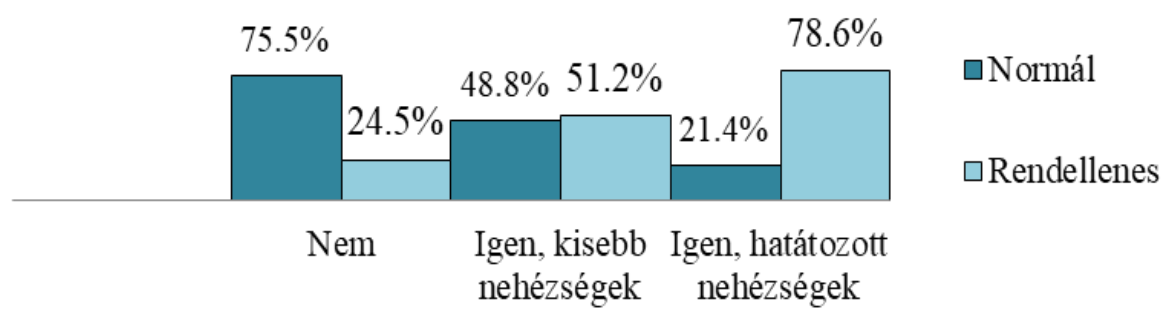

1. ábra. A megjelenő nehézségek eloszlása a figyelmi problémák szerint 


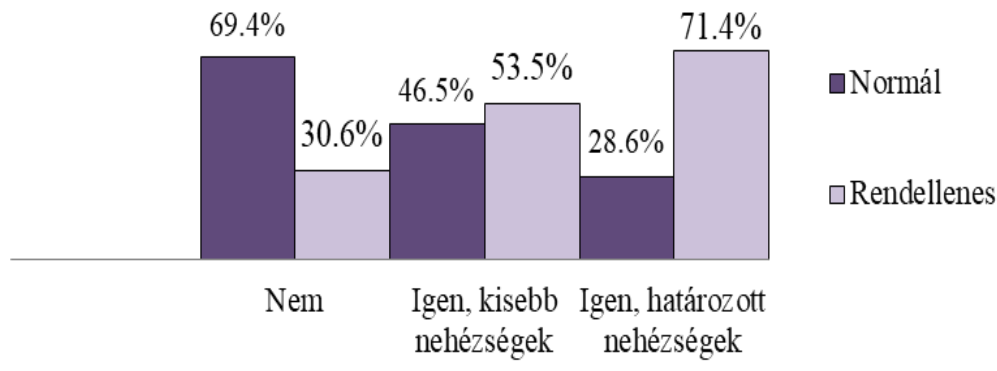

2. ábra. A megjelenő nehézségek eloszlása a hiperaktivitási problémák szerint

Kutatásunk során arra az eredményre jutottunk, miszerint azok a diákok, akik figyelmi problémákkal küzdenek többször vallanak arról, hogy kisebb $(51,2 \%)$ vagy határozott nehézségekkel $(78,6 \%)$ szembesülnek koncentráció, érzelem- és viselkedésszabályozás, valamint a szociális kapcsolatok kiépítése terén (szignifikáns együttjárást mutat a Chi négyzet próba $\chi^{2}=15,28 ; \mathrm{p}=0,00^{* *}$ ). Hasonló eredményeket találtunk a hiperaktivitási tünetekről beszámoló diákoknál is, akik esetén szintén gyakrabban tapasztalhatóak kisebb $(53,5 \%)$ vagy határozott nehézségek $(71,4 \%)$ az olyan területeken, mint a koncentráció, érzelem- és viselkedésszabályozás, valamint a másokkal való érintkezés (szignifikáns együttjárást mutat a Chi négyzet próba $\chi 2=9,28 ; \mathrm{p}=0,00^{*}$ ). Eszerint az első hipotézisünk beigazolódott.

Második hipotézisünkben feltételeztük, hogy azok a diákok, akik ADHD tünetekkel jellemezhetőek, gyengébb iskolai eredményeket érnek el, alacsonyabb a teljesítménymotivációjuk, és rögzült szemléletmóddal rendelkeznek, azon társaikhoz képest, akik nem jellemezhetőek ezekkel a tünetekkel. Kutatásunkban a résztvevők 42,5\%-a számolt be súlyosabb figyelmi problémákról és 45,3\%-a hiperaktivitási problémákról. Jelentős eltérés mutatkozott az ADHD tüneteivel élő és tünetmentes diákok iskolai teljesítménye között (magyar, román, matematika és előző félévi átlag) (lásd 1.Táblázat), minden esetben a Független mintás t-próbák eredménye szerint gyengébb a figyelmi problémákról és hiperaktivitás tüneteiről beszámoló diákok teljesítménye.

1. táblázat. Az iskolai teljesítmény az ADHD tünetek mentén

1. A. Az iskolai teljesítmény a figyelmi problémák függvényében

\begin{tabular}{|c|c|c|c|c|c|c|}
\hline & & $\mathbf{N}$ & $\mathbf{M}$ & SD & $\mathbf{t}(\mathbf{1 0 4})$ & $\mathbf{p}$ \\
\hline Magyar félévi & Normál & 61 & 8,34 & 1,85 & \multirow{2}{*}{3,55} & \multirow{2}{*}{$0,00 * *$} \\
\hline átlag & Rendellenes & 45 & 7,15 & 1,47 & & \\
\hline Román félévi & Normál & 61 & 7,67 & 1,80 & \multirow{2}{*}{2,65} & \multirow{2}{*}{$0,00 * *$} \\
\hline átlag & Rendellenes & 45 & 6,80 & 1,47 & & \\
\hline Matematika & Normál & 61 & 7,39 & 1,87 & \multirow{2}{*}{2,22} & \multirow{2}{*}{$0,02 *$} \\
\hline félévi átlag & Rendellenes & 45 & 6,62 & 1,59 & & \\
\hline Elöző félévi & Normál & 61 & 8,66 & 1,21 & \multirow{2}{*}{2,59} & \multirow{2}{*}{$0,01 *$} \\
\hline átlag & Rendellenes & 45 & 8,07 & 1,10 & & \\
\hline \multicolumn{7}{|c|}{ 1. B. Az iskolai teljesítmény a hiperaktivitási problémák függvényében } \\
\hline & & $\mathbf{N}$ & $\mathbf{M}$ & SD & $t(104)$ & $\mathbf{p}$ \\
\hline Magyar félévi & Normál & 58 & 8,53 & 1,70 & \multirow{2}{*}{4,82} & \multirow{2}{*}{$0,00 * *$} \\
\hline átlag & Rendellenes & 48 & 7,00 & 1,52 & & \\
\hline Román félévi & Normál & 58 & 7,91 & 1,72 & \multirow{2}{*}{4,36} & \multirow{2}{*}{$0,00 * *$} \\
\hline átlag & Rendellenes & 48 & 6,56 & 1,39 & & \\
\hline Matematika & Normál & 58 & 7,53 & 1,82 & \multirow{2}{*}{3,06} & \multirow{2}{*}{$0,00 * *$} \\
\hline félévi átlag & Rendellenes & 48 & 6,50 & 1,59 & & \\
\hline Előző félévi & Normál & 58 & 8,85 & 1,07 & 4,56 & $0,00 * *$ \\
\hline
\end{tabular}




\begin{tabular}{lllll} 
átlag & Rendellenes & 48 & 7,88 & 1,12 \\
\hline
\end{tabular}

Megjegyzés: $* * p<0.01, * p<0.05$

A diákok teljesítménymotivációja közötti különbséget szintén Független mintás t-próbábal vizsgáltuk (lásd 2.Táblázat). A hipotézisünk ennek a része szintén beigazolódott, hiszen a figyelmi problémák és hiperaktivitás tüneteivel jellemezhető diákoknál jelentősen alacsonyabb a teljesítménymotiváció.

2. táblázat. A teljesítménymotiváció az ADHD tünetek mentén

\begin{tabular}{|c|c|c|c|c|c|}
\hline & $\mathbf{N}$ & $\mathbf{M}$ & CD & $4(104)$ & \\
\hline Normál & $\overline{61}$ & 67.87 & 15,98 & \multirow[b]{2}{*}{3,81} & \multirow[b]{2}{*}{$0,00 * *$} \\
\hline Rendellenes & 45 & 55,69 & 16,62 & & \\
\hline \multicolumn{6}{|c|}{ 2. B. Hiperaktivitási problémák mentén } \\
\hline & $\mathbf{N}$ & $\mathbf{M}$ & SD & $\mathbf{t}(\mathbf{1 0 4})$ & $\mathbf{p}$ \\
\hline $\begin{array}{l}\text { Normál } \\
\text { Rendellenes }\end{array}$ & $\begin{array}{l}58 \\
48\end{array}$ & $\begin{array}{l}69,38 \\
54,63\end{array}$ & $\begin{array}{l}13,96 \\
17,57\end{array}$ & 4,81 & $0,00 * *$ \\
\hline
\end{tabular}

Megjegyzés: **p<0.01

Eredményeink alapján a hiperaktivitás tünetek és a mindset (intelligenciára vonatkozó szemléletmód) terén jelentős együttjárás (Chi négyzet próba $\chi 2=6,17 ; \mathrm{p}=0,01^{*}$ ) mutatható ki (lásd 4 . Ábra). A hiperaktivitás tüneteivel jellemezhetö közül közel kétszer annyian 60.4\%-uk rögzült szemléletmódúak, míg a tünetmentes diákok között csupán $36.2 \%$. A figyelem problémák esetén nem jelentős az együttjárás (Chi négyzet próba $\chi 2=1,19 ; \mathrm{p}=0,27)$. Mindezekből kifolyólag, eredményeink alátámasztják a korábbi kutatásokat, miszerint a figyelmi nehézségek és a hiperaktivitási problémák csökkentik az iskolában elért sikert.

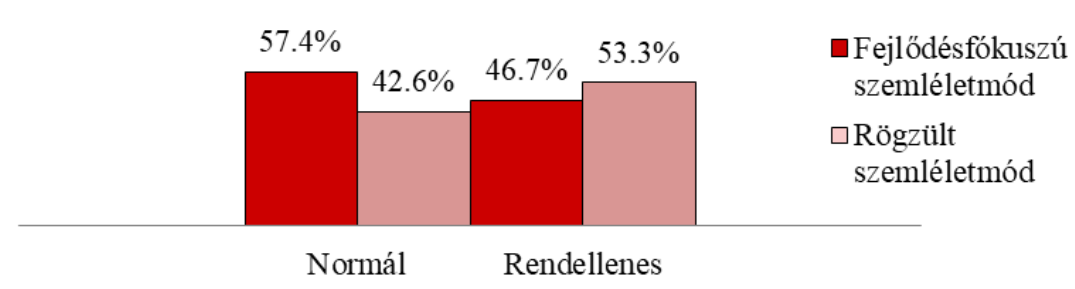

3. ábra. A diákok intelligenciára vonatkozó szemléletmódjának (mindset) eloszlása a megjelenő figyelmi problémák szerint

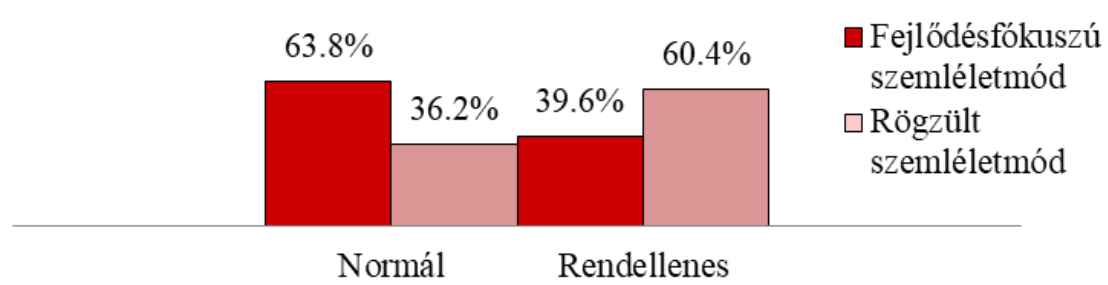

4. ábra. A diákok intelligenciára vonatkozó szemléletmódjának (mindset) eloszlása a megjelenő hiperaktivitási problémák szerint

Utolsó hipotézisként feltételeztük, hogy az ADHD-s tünetekről beszámoló diákok alacsonyabb jólléti mutatókkal rendelkeznek, mint azon társaik, akik esetén nem jelentkeznek ezek a tünetek. Független mintás t-próbával ellenőriztük feltevésünket (lásd 3.Táblázat). 
3. táblázat. A szubjektív és iskolai jóllét az ADHD tünetek mentén

3. A. A figyelmi problémák függvényében

\begin{tabular}{|c|c|c|c|c|c|c|}
\hline & & $\mathrm{N}$ & M & SD & $t(104)$ & $\mathrm{p}$ \\
\hline \multirow{2}{*}{$\begin{array}{l}\text { Szubjektív } \\
\text { jóllét }\end{array}$} & Normál & 61 & 8,64 & 3,30 & \multirow{2}{*}{1,76} & \multirow{2}{*}{0,08} \\
\hline & Rendellenes & 45 & 7,49 & 3,32 & & \\
\hline \multirow{2}{*}{ Iskolai jóllét } & Normál & 61 & 10,64 & 2,61 & \multirow{2}{*}{3,55} & \multirow{2}{*}{$0,00 * *$} \\
\hline & Rendellenes & 45 & 8,67 & 3,02 & & \\
\hline
\end{tabular}

3. B. A hiperaktivitási problémák függvényében

\begin{tabular}{llccccc}
\hline & & $\mathrm{N}$ & $\mathrm{M}$ & $\mathrm{SD}$ & $\mathrm{t}(104)$ & $\mathrm{p}$ \\
\hline Szubjektív & Normál & 58 & 8,97 & 3,44 & \multirow{2}{*}{2,84} & $0,00 * *$ \\
jóllét & Rendellenes & 48 & 7,17 & 2,97 & & \\
\multirow{2}{*}{ Iskolai jóllét } & Normál & 58 & 10,90 & 2,69 & \multirow{2}{*}{4,53} & $0,00 * *$ \\
& Rendellenes & 48 & 8,48 & 2,77 & & \\
\hline
\end{tabular}

Megjegyzés: $* * p<0.01, * p<0.05$

Eredményeink rámutattak arra, hogy azok a diákok, akik súlyosabb figyelmi és hiperaktivitási problémákkal küzdenek szignifikánsabban alacsonyabb iskolai jólléttel rendelkeznek. Ezzel szemben, a figyelmi problémák esetén nincs jelentős eltérés a tünetekkel jellemezhető és tünetmentes diákok szubjektív jólléte között, míg a hiperaktivitási problémák esetén igen.

\section{Az eredmények értelmezése és összegzés}

Jelen tanulmány a serdülő, 14-19 év közötti diákok iskolai sikerének kulcselemeit hivatott feltárni, összehasonlítva az ADHD tüneteiről beszámoló és tünetmentes serdülőket, illetve, hogy azok a diákok, akik az ADHD tünetével szembesülnek (rendellenes figyelmi és/vagy hiperaktivitási problémák), mennyire sikeresek az iskolában az olyan társaikhoz képest, akikre nem, vagy csak kevésbé jellemzőek ezek a tünetek.

Kutatásunk első hipotéziseként feltételeztük, hogy az ADHD tüneteiről beszámoló diákok (figyelem problémák és hiperaktivitás) nagyobb arányban élnek át nehézségeket az olyan területeken, mint a koncentráció, érzelem- és viselkedésszabályzás, valamint a másokkal való érintkezés. Csiky (2021) szerint az ADHD-val gyakrabban társulnak funkciógyengeségek, részképesség-zavarok, pszichiátriai kórképek. Továbbá gyakori az önkontroll hiány és az érzelmi szabályozás nehézsége. Barkley (2004) szerint gyakoriak az olyan komorbid zavarok, mint a depresszió, szorongásos zavar, deviáns viselkedés és szerhasználat. Kutatásunk során arra az eredményre jutottunk, miszerint azok a diákok, akik figyelmi és/vagy hiperaktivitási problémákkal küzdenek, jelentősebb nehézségekbe ütköznek az olyan területeken, mint az érzelmek kezelése, a viselkedés kontrollja, az összpontosított koncentráció, valamint a szociális kapcsolatok kezdeményezése, a másokkal való érintkezés.

Második hipotézisünkben feltételeztük, hogy az ADHD tüneteivel jellemezhető diákok gyengébb iskolai eredményeket érnek el, alacsonyabb a teljesítménymotivációjuk és gyakrabban rendelkeznek rögzült szemléletmóddal, azon társaikhoz képest, akik nem jellemezhetőek ezekkel a tünetekkel. Volkow (2011) vezette kutatás az ADHD-val élő és nem ADHD-s személyek tanulmányi eredményeik összehasonlítása terén, arra a következtetésre jutott, hogy azon személyek, akik figyelem- és hiperaktivitászavarral küzdenek jelentősen alacsonyabb pontszámokat kapnak mind az eredményességi, mind pedig a teljesítménymotivációt mérő skálákon. Whiteman és Novotni (1995), valamit Yee (2018) szerint az ADHD-val küzdő diákok gyakran szembesülnek negatív visszajelzésekkel és gyakori kudarcokkal, ami következtében csökken énhatékonyságuk, s inkább rögzült szemléletmódot vallanak, így, ha kudarc éri őket, azt képességeik hiányára, nem pedig a befektetett erőfeszítések hiányára vezetik vissza.

Az általunk végrehajtott kutatásban csupán három személy volt, aki valóban ADHD diagnózissal rendelkezett, azonban a résztvevők $42,5 \%$-a rendelkezett súlyosabb figyelmi problémákkal és 45,3\%-a 
hiperaktivitási problémákkal. Mindezeket figyelembe véve is, jelentős eltérés mutatkozott meg az ADHD tüneteiről beszámoló és tünetmentes diákok iskolai teljesítménye és teljesítménymotivációja között, és az intelligenciára vonatkozó szemléletmód esetén is jelentős eltérések voltak tapasztalhatóak. Mindezekből kifolyólag, eredményeink alátámasztják a korábbi kutatásokat, miszerint az olyan tünetek, mint a figyelmi nehézségek és a hiperaktivitási problémák csökkentik az iskolában elért sikert.

Wehmeier és munkatársai (2010) szerint az ADHD-val küzdő gyermekek nagyobb mértékben rendelkeznek alacsony szubjektív jólléttel, hisz tüneteikből adódóan számos problémával szembesülnek úgy mindennapi, mint iskolai helyzetben. Ebből kiindulva, utolsó hipotézisként feltételeztük, hogy az ADHD-s tünetekkel jellemezhetö diákok alacsonyabb jólléti mutatókkal rendelkeznek, mint azon társaik, akik esetén nem jelentkeznek ezek a tünetek. A vizsgálatunk során nem csak a szubjektív, hanem az iskolai jóllétet is felmértük. Kutatásunk eredményei rámutattak arra, hogy azok a diákok, akik súlyosabb figyelmi és hiperaktivitási problémákkal küzdenek szignifikánsabban alacsonyabb iskolai jólléttel rendelkeznek, azaz ritkábban szembesülnek a tanár dicséretével, gyakrabban élnek át konfliktusokat az osztálytársaikkal, vagy éppen nagyobb aggodalommal tölti el őket az iskolai feladatokkal való megküzdés. Ezzel szemben, a figyelmi problémák esetén nincs jelentős eltérés a tünetekröl beszámoló és tünetmentes diákok szubjektív jólléte között, míg a hiperaktivitási problémák esetén igen. Mindez talán azzal magyarázható, hogy míg a figyelmi nehézségek nem befolyásolják oly nagy mértékben a diákok nem iskolához kapcsolódó szokásait, így gyakrabban érezhetik magukat vidámnak és jókedvűnek, ellazultnak, élénknek, addig a hiperaktivitási tünetek erősebb befolyást fejtenek ki a mindennapokra is, így az ilyen tünetekkel szembesülő serdülő, ritkább esetben tapasztalhatja meg a nyugodt, ellazult állapotot, ami negatív érzelmekkel is társul.

Kutatásunkat összegezve, azt a következtetést vonhatjuk le, hogy az ADHD tünetei (figyelmi és hiperaktivitási problémák) alacsonyabb iskolai sikerrel társulnak, hisz különbségeket találtunk úgy a tanulmányi teljesítményben, mind a teljesítménymotivációban, mind pedig az iskolai jóllétben. Továbbá a szemléletmódban és szubjektív jóllétben csupán a hiperaktivitást mutató diákoknál találtunk jelentős különbséget. Mindazonáltal érdemes lenne a fejlődési szemléletmód kialakítására fókuszálni, hiszen a szemléletmód szoros összefüggést mutat az iskolai sikerrel. Ezáltal vizsgálhatnánk további kutatásokban a szemléletmódot fejlesztő beavatkozások hatását.

\section{Irodalomjegyzék}

Aldridge, J. M., Fraser, B, J., Fozdar, F., Ala'i, K., Earnest, J., \& Afari, E. (2016). Students' perceptions of school climate as determinants of wellbeing, resilience and identity. Improving Schools, 19(1), 5-26. https://doi.10.1177/136548021561261

APA - American Psychiatric Assosiation (2013). Diagnostic and statistical manual of mental disorders, Fifth Edition (DSM-5). American Psychiatric Publishing, Washington, DC London, England.

Barkley, R. A. (2004). Adolescents with attention-deficit/hyperactivity disorder: an overview of empirically based treatments. Journal of Psychiatric Practice, 10, 39-56.

Csiky M. (2021). A hiperaktivitás és figyelemzavar tünetegyüttes képének alakulása a különbözö életkorokban. A beavatkozás lehetöségei. ADHDoki, MRE-Bethesda Gyermekkórháza, Svábhegyi Gyermekgyógyintézet.

Dovis, S. (2014). Cognitive Control and Motivation in Children with ADHD: How Reinforcement Interacts with the Assessment and Training of Executive Functioning. Ipskamp Drukkers bv, Enschede

Dweck, C. (1999). 'Kind of Person' Implicit Theory Scale. Retrived from http://sparqtools.org/mobility-measure/kind-of-person-implicit-theory-scale/

Dweck, C. (1999, 2006). Growth Mindset Scale. Retrived from http://sparqtools.org/mobilitymeasure/growth-mindset-scale/ 
Dweck, C. (2000). Self-theories: Their role in motivation, personality, and, development. Philadelphia, PA: Psychology Press.

Dweck, S. C. (2006). Mindset: The new psychology for success. Ballantine Books, New York.

Elliot, A. J., Murayama, K., \& Pekrun, R. (2011):. A 3×2 achievement goal model. Journal of Educational Psychology, 103(3), 632-648.

Fejes E., Kun Á., \& Medvés D. (2015). A jóllétet meghatározó tényezők vizsgálata egészségügyi szakdolgozók körében. Alkalmazott Pszichológia, 15(2), 49-71.

Fodor L. (2007). Fejezetek a motivációkutatásból. Gondolat Kiadó, Budapest.

Goodman, R. (1997). The Strengths and Difficulties Questionnaire: a research note. Journal of Child Psychology and Psychiatry, 38(5), 581-586.

Hamvai Cs., \& Pikó B. (2009). Serdülők szubjektív jóllétét meghatározó társas tényezők a családban és az iskolában. Pedagógiai Folyóirat, 4.

Hascher, T. (2004). Wohlbefinden in der Schule. Münster: Waxmann Verlag.

Imre S. (2004). Disorders of executive consciousness. Ideggyógyászati Szemle, 57(9-10), 292-300.

Nagy K., Jámbori Sz., Gál Z., \& Kasik, L. (2019). A tanulói jóllét és az önértékelés jellemzőinek feltárása középiskolások és egyetemisták körében. Iskolakultúra, 29, 3-17. https://doi.10.14232/ISKKULT.2019.6

National Institutes of Mental Health (2016). Attention-Deficit/Hyperactivity Disorder (ADHD): The Basics. Department of Health and Human Services.

Robin, A. L., \& Vandermay, S. J. (1996). Validation of a measure for adolescent self-report of attention-deficit disorder symptoms. Journal of Developmental and Behavioral Pediatrics, 17, 211215.

Vieno, A., Santinello, M., Galbiati, E., \& Mirandola, M. (2004). School climate and well being in early adolescence: A comprehensive model. European Journal of School Psychology, 2(1-2), 219-238.

Volkow, N. D., Wang, G. J., \& Swanson, J. M. (2011). Motivation Deficit in ADHD is Associated with Dysfunction of the Dopamine Reward Pathway. Molecular psychiatry, 16(11), 1147-1154.

Wehmeier, P. M., Schacht, A., \& Barkley, R. A. (2010). Social and Emotional Impairment in Children and Adolescents with ADHD and the Impact on Quality of Life. Journal of Adolescent Helath, 46(3), 209-2017.

Whiteman, T. A., \& Novotni, M. (1995). Adult ADD. Pinon Press, Colorado.

WHO (1998). WHO (Five) Well-being Index (WHO-5). Psychiatric Research Unit. Mental Health Centre, North Zealand, Hillerød, Denmark.

Yee, A. (2018). Being Strength-Minded: An Introduction to Growth Mindset. Foothills Academy. Retrived from https://www.foothillsacademy.org/community-services/parent-education/parent$\underline{\text { articles/growth-mindset }}$

\section{Szerzők}

Bányai Brigitte-Ildikó, Babeș-Bolyai Tudományegyetem, Alkalmazott Pszichológia Intézet, Kolozsvár (Románia), E-mail: brigi_banyai@yahoo.com

Jancsó-Farcas Susana, Babeș-Bolyai Tudományegyetem, Alkalmazott Pszichológia Intézet, Kolozsvár (Románia), E-mail: zsuzsannapsy@gmail.com 


\section{Köszönetnyilvánítás}

A jelen kutatás része Bányai Brigitte-Ildikó mesteri disszertációjának, amit Jancsó-Farcas Susana irányításával végzett. 